\title{
EVALUATION STUDY OF ENGLISH TEXTBOOK FOR INDONESIAN JUNIOR HIGH SCHOOLS
}

\author{
Nurul Lailatul Khusniyah \\ Universitas Islam Negeri Mataram, nurullaila@uinmataram.ac.id
}

\begin{abstract}
This study aims to figure out the quality of the English textbook for Junior High School designed by the government. Specifically, it was to examine if the textbook was appropriate for the students' needs according to their levels and context. Content analysis was applied for the evaluation. Model of evaluation was Discrepancy Evaluation Model (DEM) used to know suitability or unsuitability of textbook based on the criteria of evaluation. The instrument of assessment had 8 criteria, namely goals, approach, language content, skills, topics, methodology, teacher's book, and practical consideration. The instruments were validated by experts on the area. The findings showed that the English textbook "Babasa Inggris Think Globally Act Locally Class IX" had a good quality as evidenced from from the percentage of criteria, such as goals $80.8 \%$, approach $82.8 \%$, language content $81 \%$, skills $81.3 \%$, topics $87 \%$, methodology $78.8 \%$, teacher's book $56.8 \%$, and practical consideration $82.3 \%$. For this reason, it is highly recommended for using the book at Junior High School.
\end{abstract}

Keywords: English Learning, Textbook, Quality

\section{INTRODUCTION}

Textbook has a positive impact on successful learning. It is an integral element of English teaching and learning process as a foreign language in Indonesia. Thus, the textbook is as a main operational source of formal study. As Graves (2000) said, that the textbook is a book used as a standard source of information for the formal study of a subject and an instrument for teaching and learning. From that concept, it is known as one of many sources teachers can create the creative effects of the lesson. 
The selection of English learning material has considered the quality and procedure to assess the textbook, so it will be appropriate with the students' needs and context. It shows that accurate selection textbook can be helped the students and teacher in the learning and teaching process. Cunningsworth (1995) believes that "a resource in achieving aims and objectives that have already been set in terms of learner needs". It can be concluded that the teacher has to know the quality of the textbook used in the classroom. It means that English learning for Junior High School has four language skills. Therefore, the quality of the textbook is not only referring to content, language, and grammatical but also an illustration of the textbook. How is the diction of words and text narration? These creating will be given the impact of learning process quality.

Some teacher always used the textbook without need analysis process of learning. They adopt the textbook in the English learning process as fully. Many teachers are required to use textbooks and are bound to the textbook in its existing form. Then, the teacher should teach using a textbook. Thus, the teacher delivers the knowledge of English learning to master four skills and some value in each content. Hutchinson and Torres (1994), the importance of the textbook becomes even greater in periods of change. Textbooks may function as intermediary roles and potential agents for change during educational innovation due to a number of reasons; first textbooks act as a vehicle for teacher and learner training; second textbooks provide a picture of what the change will look like; and third, they provide the psychological support to teachers

While in the preliminary study it can be concluded that the teacher teaches textbook. It is not a good impact on students' memory in learning. Because the process of learning teaching has different situational and always change. It depends on the students' situation and the teacher's way of teaching. In other words, the teacher has to know about the advantages of a textbook that will 
Khusniyah, N. L., English Textbook ... Edulangue Vol 2 (1) 2019 change the learning situation. So, it is a problem when the teacher cannot comprehend how to use the comprehensive textbook. 
The result of preliminary observation, Indonesia has created the textbook that can be used by the school is known as Buku Sekolah Elektronik. Each student and teacher can download and use it as easy, like as Bahasa Inggris Think Globally Act Locally Class IX. In this textbook has arranged as curriculum 2013 to face the learning model in century 21. It shows the process of learning from teacher to students. The content has used English as fully. The presentation of the textbook used the text-based learning approach, both orally and written that put English as the communication media. The communication content refers to daily communication, because English learning has taught formally in Indonesia for Junior High School.

The textbook is a part of curriculum 2013 that emphasized to make the harmony of attitude competence, knowledge, and skills, English language ability is made through continues learning. Thus, the students have to achieve the expected competence as an approach used in curriculum 2013. But, the problem is known that some teacher usually used the textbook without the evaluation process of the textbook. Considering the textbook as a source of the lesson, it expected to contain clear material, accurate, and recent. Consequently, it needs the evaluation process of the textbook to know the suitability of textbook content through evaluation of foreign language textbook that is having quality.

Therefore, this study has aims to know the quality of the English textbook for Junior High School Class IX. The problem formulation is; How is the quality of English textbook for Junior High School Class IX?

\section{LITERATURE REVIEW}

\subsection{Textbook}

Textbook has the main role in the learning process. Brown (2007) stated that the most important thing in language teaching materials is the textbook. Sometimes the new teachers make interesting teaching materials, good material for students, however, 
Khusniyah, N. L., English Textbook ... Edulangue Vol 2 (1) 2019 they ignore the standard values of textbooks that are in line with the school curriculum and neglects that these sources are actually 
very useful. From this concept, the teacher has to make the textbook that has standard value in the curriculum. Hutchinson dan Torres (cited in Crawford 2002, p. 83) argue that textbook is as a possible agent for change. Furthermore, Teachers are very autonomous in their textbook use and .... it is likely that only a minority of teachers really follow the text in the page by page manner suggested in the literature (Murray \& Christison, 2011, p. 53). It can be concluded that the textbook not only always determines the teaching and learning process, but rather the spread where the teacher and students do it. Because textbooks are often widely written for students, the teacher writes them through the adaptation of the textbook where they or the school has. This certainly includes changing activities and texts in textbooks or additional material in textbooks.

Furthermore, Hutchinson shows variations in the use of textbooks that are influenced by factors; 1) textbooks (content of the book), 2) teachers (beliefs, training, pedagogic and content of knowledge, experience, teaching style, perceptions and evaluations of textbooks, attitudes), 3) students (level of skill, previous learning experience), 4) class (design), and 5) school (cited in Harwood, 2014, p. 12).

In the process of selecting various textbooks, we must be truly selective and consider various quality standards that have been set. The textbook that we choose should be the one that can support the quality of learning carried out. Books that consist of diverse material and can foster student enthusiasm not only eliminate the enthusiasm and motivation of students to learn English.

Cunningsworth (1995) stated the criteria of the textbook as follow: (1) Coursebooks should correspond to learners' needs. They should match the aims and objectives of the language program; (2) Coursebooks should reflect the uses (present or future) that learner will make of the language. Textbooks should be chosen that will help equip students to use language effectively for 
Khusniyah, N. L., English Textbook ... Edulangue Vol 2 (1) 2019 their own purpose; (3) Coursebooks should take account of students, need as learners and should facilitate their learning 
processes, without dogmatically imposing a rigid" method"; (4) Coursebook should have a clear role as a support for learning, like teachers, they should mediate between target language and the learner

The following list contains the most frequently stated advantages of using textbooks (Graves , 2000; Basturkmen, 2010):

1) It provides a syllabus for the course because the authors of the syllabus have made decisions about what will be learned and in what order.

2) It provides security for the students because they have a kind of a road map of the course: they know what to expect and they know what is expected from them.

3) It provides a set of visuals, activities, readings, etc., and so saves the teacher time in finding or developing such materials.

4) It provides teachers with a basis for assessing students' learning. Some textbooks include tests or evaluation tools.

5) It may include supporting materials (teacher's guide, cd, worksheets, and video.)

6) It provides consistency within a program across a given level, if all teachers use the same textbook. If textbooks follow a sequence, as within a series, it provides consistency between levels.

Textbooks also have limitations, which can lead to teachers' and learners' dissatisfaction with the course. The following list contains the most frequently stated disadvantages of using only ready-made textbooks (Graves, 1996; Basturkmen, 2010):

1) The content or examples may not be relevant or appropriate to the group and they may not reflect the students' needs since textbooks are often written for global markets and often do not reflect the interests and needs of students.

2) They may contain inauthentic language, since texts, dialogs and other aspects of content tend to be specially written to 
Khusniyah, N. L., English Textbook ... Edulangue Vol 2 (1) 2019 incorporate teaching points and are often not representative of real language use.

3) The content may not be at the right level. 
Khusniyah, N. L., English Textbook ... Edulangue Vol 2 (1) 2019

\subsection{Criteria of Textbook Analysis}

Analysis of textbook is basically a matching process, which is matching the desired needs to the possibilities available. Textbook analysis is essentially a systematic value assessment of the values and objectives of the book itself and the purpose of students who use the book analysis can be in the form of pre-use analysis that emphasizes predictable and potential values, analysis post-use that is the analysis carried out on what has happened as a result of the use of teaching materials (Tomlinson, 2011)

There are many criteria that can be used in analyzing textbooks, depending on the conditions and priorities of an individual. According to Chunningsworth (1995), there are eight general criteria that considers most important in the process of analysis and selection of textbooks:

a) Goals

b) Approach

c) Language content

d) Skills

e) Topics

f) Methodology

g) Teacher's book

h) Practical considerations.

Chambliss and Caffee (1998) assess textbooks from three aspects, namely:

a. Ease of understanding (comprehensibility)

b. Curriculum

c. Instructions.

Each of these aspects is assessed again in terms of themes, elements, and relationships (linkage). In terms of the theme the content of the book must be familiar to students, interesting and the structure is coherent, so that it is clear and easy to understand. In terms of instruction, the learning model must be studentcentered and use the principle of constructivism. 
Khusniyah, N. L., English Textbook ... Edulangue Vol 2 (1) 2019

\section{METHOD}

The research method used evaluation study through content analysis technique. The study used Discrepancy Evaluation Model (DEM) that is used to know the criteria of textbook evaluation. Krippendorff (2004) stated that "content analysis is a research technique for making replicable and valid inferences from texts (or other meaningful matter) to the context of their use." It has the similar concept with Mayring theory. According to Mayring (2014), content analysis technique can be factually valid technique, replication to make specific conclusion of textbook. It can be controlled as methodology and empiric with using the role of analysis phase that is not given early qualification. Therefore, the process of assessment the English textbook for Junior High School class IX is appropriate with that theory.

The research data is taken from English textbook for Junior High School Grade IX that has published by Pusat Kurikulum dan Perbukuan, BalibangKemendikbud Indonesia. It is Bahasa Inggris Think Globally Act Locally Class IX .The criteria of textbook evaluation refer to Cunningsworth's concept. There are 8 criteria, namely goals, approach, language content, skills, topics, methodology, teacher's book, and practical considerations. Validation of instrument is done through judgment expert. The procedures of research are discussion, ask and answer. The expert gives some critic and suggestion for the instrument of research. The purpose is to complete the assessment of foreign language textbook instrument. After that, instrument revised, recheck again by expert and the finally, there is getting valid instrument to use an instrument of collecting data. Besides that, the data is gotten through questionnaires and interview.

\section{FINDINGS AND DISCUSSIONS}

Based on the analysis result, it is known that the quality of Bahasa Inggris Think Globally Act Locally Class IX comes from each 
Khusniyah, N. L., English Textbook ... Edulangue Vol 2 (1) 2019

component and all of the textbook component. Here is the result of the textbook assessment;

Table 1. Quality of English Textbook for Junior High School 
Khusniyah, N. L., English Textbook ... Edulangue Vol 2 (1) 2019

\begin{tabular}{cc}
\hline $\begin{array}{c}\text { Criteria of } \\
\text { Assessment }\end{array}$ & Percentage \\
\hline Goals & $80.8 \%$ \\
Approach & $82.8 \%$ \\
Language content & $81 \%$ \\
Skills & $81.3 \%$ \\
Topics & $87 \%$ \\
Methodology & $78.8 \%$ \\
Teacher's book & $56.8 \%$ \\
Practical considerations & $82.3 \%$ \\
\hline Note : & \\
$76-100 \%$ : Good & \\
$51-75 \%:$ Less Good & \\
$26-50 \%:$ Not Good & \\
$0-25 \% \quad:$ Very Not Good &
\end{tabular}

Table 1 show that the English textbook "Bahasa Inggris Think Globally Act Locally Class IX" has a good quality and appropriate with the evaluation criteria of the textbook assessing. It is as manifested as high-quality books. English textbook has 14 chapters. The English textbook has a high value taught to the students and it fulfills the Government concept to build the character building education. Then, each student has soft skills and hard skills that are able to support their knowledge.

The goals of the textbook have been designed using the 2013 curriculum. It is designed to face the 21st-century learning model. There is a shift in learning from students told to be students to find out from various learning sources beyond teacher limits and educational units. English learning for Class IX in grade Junior High School is structured to improve students' language skills.

The presentation uses a text-based learning approach, both oral and written, by placing English as a means of communication. Understanding of the type, rules, and context of a text is emphasized so that it makes easier for students to capture the 
Khusniyah, N. L., English Textbook ... Edulangue Vol 2 (1) 2019 meaning contained in a text and present ideas in the form of appropriate text. It is easily understood by others. Since the new 
English is officially taught starting in Class IX, the communication presented is daily communication.

Language content has been adjusted to the 2013 curriculum content. As part of the 2013 Curriculum which emphasizes the importance of the balance of attitude, knowledge and skills competency, English language skills are formed through continuous learning. Learning model begins with an increase in the competence of knowledge about the types, rules, and context of a text, followed by competency skills to present a written and oral text both planned and spontaneous with proper pronunciation and intonation. This continuous learning leads to the formation of a politeness-speaking attitude.

Dealing with four language skills, namely listening, speaking, reading and writing, these skills are put in various activities. The first is observing and questioning that is as warming up activity to share information. The second is collecting information that shown grouping activity. The third is reflecting that lead the students to reflect on what you are learning. The fourth is associating related to students' experience and context of life. Language skills refer to fulfill needs of language proficiency that is suitable with situation and condition faced. Presenting is in the third rank because a good presenting can complete the perfection of the book to bring up the students' attractiveness to learn. The fifth is communicating that shown the way of students in learning.

Topics of the textbook have variations of value. There are communicative competence and grammatical concept. Besides, each topic has different value to teach real life, such as the greeting, healthy, the action, home, earn, culture, and Indonesia. In other research, it is shown the same concept in learning. The results obtained from the study suggests that the three books are carefully designed to meet the MNE curriculum goals and objectives, to serve as potential agents for curriculum change and to meet young learners' needs and interests. This study has been conducted three years after the first implementation of the new textbooks. It is 
Khusniyah, N. L., English Textbook ... Edulangue Vol 2 (1) 2019

suggested that such evaluation of textbooks should be done on a regular basis to give further insights into the future revision and/or 
designing of the textbooks for young learners of English (Kirkgöz, 2009).

Other research considers whether English textbooks are contextualized enough to help with students' English learning and communication. This is achieved by analyzing a set of secondary English textbooks Project English used in China and discovering textbook users' real experience of learning English and using English textbooks. The results show that topics, texts, and tasks of textbooks are decontextualized in terms of authenticity, levels of communication, diversity, and representation of cultures. Moreover, more attention is given to grammatical functions of the English language rather than its communicative functions(Huang, 2019). It is the same with Zarei and Khalessi (2011).

The methodology presented using student-centered learning. The students have the main role in the classroom and the teacher is a mediator of learning. Teacher's book is not designed but it refers to the process of direct learning. Therefore, the last criteria are practical consideration refers to the ways of a teacher in the learning process. The students always practice in the classroom.

\section{CONCLUSION AND IMPLICATIONS}

The result of the analysis is to know the textbook quality that is used by teachers in Junior High School. This book has relevance with the context of life. Each student can get this textbook using internet network. All of the components in the English textbook have a high percentage. So, it refers to eligible in the English language learning process for students in Junior High School. This study has given implication as practical to the Government in preparing the textbook. The essence if English textbook considered the standard value that can be used in real life. But, the government has to give more attention to the difficulty level.

\section{REFERENCES}

Basturkmen, H. (2010). Developing courses in English for specific purposes. 
Khusniyah, N. L., English Textbook ... Edulangue Vol 2 (1) 2019

New York: Palgrave Macmillan. 
Khusniyah, N. L., English Textbook ... Edulangue Vol 2 (1) 2019

Brown, H. D. (2007). Teaching by principles: An interactive approach to language pedagogy. New York: Pearson Education, Inc

Tomlinson, B. (2011). Material development in language teaching (2nd ed.). Cambridge: Cambridge University Press

Cunningsworth, A. (1995). Choosing your cursebook. Oxford: Heinemann

Crawford, J. (2002). The role of materiasl in language classroom: Finding the balance, methodology in language teaching, $e d$,. In J. C. Richard \& W. A. Renandya (Eds), Methodology in language teaching: An anthology of current practice (pp. 80-92). New York: Cambridge University press

Graves, K. (1996). Teachers as course developers. England: Cambridge University Press.

Graves, K. (2000). Designing Language Course, A Guide for Teachers. Boston. Heinle. Cengage Learning.

Hutchinson, T., \& Torres, E. (1994). The textbook as agent of change. ELT Journal, 48, 4, 315-328

Harwood, N. (2014). English Language Teaching Textbooks Content, Consumption, Production. New York: Palgrave Macmillan

Huang, P. (2019). Textbook interaction: A study of the language and cultural contextualisation of English learning textbooks. Learning, Culture and Social Interaction, 21, 87-99.

Kurkgöz, Y. (2009). Evaluating the English textbooks for young learners of English at Turkish primary education. Procedia Social and Behavioral Sciences, 1(1), 79-83.

Krippendorff, K. (2004). Content analysis: An introduction to its methodology (2nd ed). Thousand Oaks, CA: Sage

Mayring, P. (2014). Qualitative content analysis: Theoritical foundation base procedures and sofware solutiaon. Austria: Klagenfurt

Murray, D. E., \& Christison, M. A. (2011). What english language teachers need to know volume II: Facilitating learning. New York: Routledge

Zarei, G. R., \& Khalessi, M. (2011). Cultural load in English language textbooks: An analysis of interchange series. Procedia Social and Behavioral Sciences, 15, 294-301. 